\title{
THE GENERAL ASSEMBLY
}

$$
\text { July ro, I935 }
$$

The President took the chair at $\mathrm{I} 4.00$ and opened the meeting with the following remarks.

\section{LAdies AND GeNTlEMEN,}

It is a great pleasure to declare open the Fifth Meeting of the International Astronomical Union in such beautiful surroundings, and in a sense to regularize the Union by coming to Paris, the mother of astronomical conventions and the centre of so many of our activities, as, for example, the Carte $d u$ Ciel and the Bureau de l'Heure.

First of all, I ask you to rise and to stand for a few moments in silent respect to the memory of those of our members whom we have lost since we met three years ago in America. This morning I said a few words concerning the loss we have suffered in the death of our first president, Benjamin Baillaud. He was a lovable colleague, a great astronomer and administrator, a gentleman of France. A few months after his death we lost another of our former presidents, Willem de Sitter of Leiden. Baillaud died full of years and with his work done, but de Sitter died at a comparatively early age, and in the midst of many important projects which must now be carried out by his successors. In his death Astronomy has lost one of her most distinguished votaries, the Union has lost one of its staunchest supporters, and many of us here have lost a close friend.

There is time this afternoon merely to read the names of the others whom we have lost, though the list contains some very distinguished names:

\author{
Dr A. Belopolsky \\ Rev. P. Berloty \\ Mr A. N. Brown \\ Prof. C. V. L. Charlier \\ Prof. D. Eginitis \\ Rev. T. E. Espin \\ $\mathrm{Dr}$ W. J. Fisher \\ Vice-Admiral Fournier \\ Prof. E. B. Frost \\ Prof. F. Gonnessiat
}

\author{
Dr J. Kaván \\ Dr W. E. Kruytbosch \\ Mr E. Leroy \\ Dr J. Mascart \\ Prof. P. Painlevé \\ General T. Ramniceanu \\ Mr A. N. Ribeiro \\ Dr C. E. St John \\ General Vacchelli \\ Abbé Verschaffelt
}

Our next duty is to elect the Recorders for the meetings of the General Assembly. Would Mr Chrétien and Mr Antoniadi kindly help in this work?

In the absence of Dr Nušl through ill-health the Executive Committee nominates Dr Nechvile as Vice-president for the meeting.

If it is your wish I will ask the Secretary to cable our greetings and good wishes to Profs. Hale, Campbell, and Nusl, and to Dr Kimura, who has directed our latitude work so long and so successfully; he is unable to be present to-day, largely for reasons of health. I am sure you will also wish to send a telegram of condolence to Mrs de Sitter. 
I am glad to report that since the printing of the Executive Committee's report, which is in your hands and which is now presented for adoption, China has formally joined the Union. I am sure that the General Assembly would wish to show their appreciation of this and also of the recent adhesion of the U.S.S.R., as mentioned in that report. I have also received letters from German friends that make it clear that they would join the Union if it were not for difficulties of a financial order. I sincerely trust that they will have joined us before our next meeting.

I have now to announce the committee on the personnel of the standing commissions. The Executive Committee has chosen the following: Prof. Abetti (Chairman), Messrs Bergstrand, Carrasco, Coculesco, da Costa Lobo, Fayet, Gerasimovic, Hins, Kamieński, Knox-Shaw, J. S. Plaskett, Russell, Sotome, E. Strömgren, Stroobant, and Svoboda.

We now pass to a consideration of an amendment to our By-laws proposed by Great Britain. The new point in the amendment is that the Executive Committee (or the personnel committee which advises it) should consult the outgoing president of a commission (or in case he is absent his substitute for that meeting) in preparing their lists of new members for submission to the General Assembly. This is already a tradition in the Union. I have discussed the matter with the representatives of Great Britain and they agree that a resolution of this meeting without a change of By-laws (with all its accompanying minor troubles in official voting, reprinting and notification to all countries) would meet the case. If no one objects, I will ask the Assembly to accept this proposition as a simple resolution adopted by the Assembly. As I hear no objection, I take it that this resolution is approved.

I have next to report that the Presidents of three of our Commissions, I9, 22 and 25, are absent from our meeting. The Executive Committee has nominated $\mathrm{Mr}$ W. D. Lambert, Mr De Roy and Prof. Bergstrand to preside at this meeting in their places respectively.

With regard to resolutions $(a)$ and $(b)$ on the agenda submitted by Great Britain and Belgium respectively, the Executive Committee suggests that they be referred to a joint meeting of Commissions 3 and 4 , to be presided over by Prof. Strömgren. Resolution (c) from Belgium involves financial considerations and is referred to Commission 3 for report.

Resolution $(d)$ submitted by the French National Committee calls for decision at this meeting, and I will ask M. Danjon to speak to it.

M. Danjon explained that the reason why the separation of Commission 16 had been suggested by the French National Committee was because the Commission as at present constituted consisted of those especially interested in the morphology of planets and not of those interested in the more recent astrophysical developments.

Prof. Russell realised fully the difficulties to which the French Committee had drawn attention but felt that a better solution could be adopted than the one suggested. He did not see how the morphological and astrophysical studies could properly be separated. For instance, recent important advances had been made in the knowledge of the atmospheres of the major planets: methane and ammonia were now known to be present in the atmosphere of Jupiter and variations in the colour of the markings might be due to movements of clouds of crystals of ammonia. The problems of the morphology of Mars and Venus were closely connected with the chemical composition of their atmospheres, while still closer relations held in the case of comets. Here it was clearly undesirable or even impossible to make the separation suggested. It would be preferable to separate comets and planets, but to keep the morphology and astrophysics of each group together. 
The President said that it was difficult to believe that Prof. Russell had not been at the meeting of the Executive Committee when the French resolution was discussed. Their view was that it was more important to bring these subjects closer together than to separate them. He would ask whether the French Committee would be willing to withdraw the resolution. A further suggestion had been made to the Executive Committee, namely that it was important for co-operative study of the zodiacal light to be encouraged by the Union. It was too small a subject for a separate commission but perhaps they might have a commission on comets, zodiacal light and related phenomena.

Dr Donitch stated that he had done considerable work on the zodiacal light in Egypt and was preparing for further work. In his view the zodiacal light was to be regarded as an extension of the corona and it should preferably be referred to a committee dealing with the corona. The link was rather with the corona than with comets.

Prof. Russell said that he was in favour of the President's suggested new commission but he would exclude the zodiacal light.

The President suggested that we should make a commission on comets, meteors and related phenomena. Prof. Russell suggested that this might adversely affect meteoric astronomy which was now fully developed. Miss Harwood raised the question under which commission asteroids would come and Prof. J. S. Plaskett asked whether it would not be best to consult the commission on meteors.

The President said that the whole question and a minute of the discussion should be referred to Commission 22. They would now pass on to Proposition (e), also from the French national committee, with regard to a new commission on occultations. Prof. Brown of Yale had been occupied with this matter for some years and they had discussed the question together. The work was well in hand and they did not see the need for burdening the Union with a fresh committee. He would invite Dr Brouwer to speak to the motion.

Dr Brouwer said that further work on star places in connection with occulfations had to be considered but he did not think that the matter could be advanced by a special committee of the Union.

Dr Hins said that at Leiden they had observed 1600 stars fainter than $9^{\mathrm{m}}$ for occultations. It was important to secure co-operation and it would be an advantage to have a special commission, as these stars would not come under the care of Commission 8 on meridian astronomy. To use only A.G. stars would not fit in with an economic observational programme, and the stars concerned were fainter than A.G. stars.

M. Danjon said that it was important to organize these observations of the faint stars, to study the technique of such observations and to prepare maps for facilitating them.

Dr Brouwer said that as it was they already received Iooo occultations a year, which were amply sufficient. It was unnecessary to take steps to extend the programme.

Dr Smart suggested that the whole matter be referred to Commissions 8 and $\mathbf{I} 7$ to report to the next General Assembly.

The President pointed out that in a few years we should have for all the A.G. stars in the ecliptic well-determined positions and proper motions. Dr Brouwer's point about number was important. Apparently we might have to discourage rather than to encourage observations. In the absence of Prof. Brown he suggested that the matter might be referred to the next General Assembly. 
Dr J. Jackson said that Commission 8 could look after the positions of the fainter stars required.

Dr Robertson said that he had a good deal to do with the use of occultations for correcting the moon's path for eclipse calculations. Only two or three hundred a year of those supplied could be used. He would favour a new commission.

The President said that plans were on foot for getting good positions and proper motions of the stars used and if the occultations could not all be used now they could be worked up later. He suggested that the matter be referred to the next meeting. This was agreed to by a majority vote.

Prof. Leuschner said that the General Assembly was too large a body to decide such a question. He moved that it be referred to the Executive Committee with power to act. This was carried nem. con.

The following were then nominated by their respective countries to serve on the Finance Committee:

$\begin{array}{ll}\text { Argentine Republic } & \text { Dr ZIMMER } \\ \text { Belgium } & \text { Dr DELVOSAI } \\ \text { Canada } & \text { Prof. CHANT } \\ \text { China } & \text { Mr KAO-PING-TSE } \\ \text { Czecho-Slovakia } & \text { Dr MOHR } \\ \text { Denmark } & \text { Miss VINTER HANSEN } \\ \text { Egypt } & \text { Dr MADWAR } \\ \text { France } & \text { M. DANJON } \\ \text { Great Britain } & \text { Sir FRANK DYSON } \\ \text { Holland } & \text { Prof. NIJLAND } \\ \text { Italy } & \text { Prof. SILVA } \\ \text { Japan } & \text { Prof. SotOME } \\ \text { Norway } & \text { Prof. RosSELAND } \\ \text { Poland } & \text { Prof. WITKOWSKI } \\ \text { Portugal } & \text { M. DOS REIS } \\ \text { Roumania } & \text { M. PARVULESCO } \\ \text { Spain } & \text { M. TINOCO } \\ \text { Sreden } & \text { Prof. LINDBLAD } \\ \text { Sreitzerland } & \text { Prof. BRUNNER } \\ \text { United States } & \text { Dr ADAMS } \\ \text { Vatican City } & \text { FATHER STEIN }\end{array}$

The President appointed Sir Frank Dyson Chairman of the Finance Committee and then adjourned the General Assembly to Wednesday, July I7th, at ro o'clock. 